\title{
Reanalysis in Hungarian Comparative Subclauses
}

\begin{abstract}
My paper presents a diachronic study of the Left Periphery of Hungarian comparative subclauses, primarily focussing on the development of the complementisers and the operator. Adopting the Principles and Parameters framework, I will show that there were two main interrelated processes at work in the development of these subclauses, changing the initial configuration of hogy 'that' as a complementiser to a new one having mint 'than' as a $\mathrm{C}$ head, possibly followed by an overt operator. These two processes are the reanalysis of mint from an operator to a complementiser by way of the relative cycle, and the appearance of new overt comparative operators due to a change in the parametric setting with respect to the deletion of the operator.
\end{abstract}

\section{The problem}

Adopting the framework of the Principles and Parameters theory, the aim of the present paper is to present a diachronic study of the Left Periphery of Hungarian comparative subclauses ${ }^{1}$, primarily focussing on what changes led to the syntactic structure characteristic of Modern

\footnotetext{
${ }^{1}$ Throughout this paper I will restrict myself to the analysis of clausal comparatives expressing inequality. The reason for this is because the syntactic behaviour of clausal comparatives expressing equality is crucially different. On the other hand, phrasal comparatives (i.e. where the subclausal CP is replaced by a DP) would be even more demanding to analyse here.
} 
Hungarian and what parametric differences can be traced between Old and Modern Hungarian.

In Modern Hungarian, the comparative subclause is introduced by mint 'than', which may be followed by an overt comparative operator (e.g. ahányszor 'x-many times'). However, in Old Hungarian the subclause was initially and typically introduced by hogy 'that', and the comparative operator remained covert. Though the two stages seem to be radically different, I will show that the latter can actually be derived from the former by means of purporting the development of the complementiser and that of the operator to be two interrelated processes, the most important aspects of the changes being the reanalysis of the complementiser mint 'than' and the change in the deletion of the operator.

In the next part of the article I will provide a theoretical background by briefly presenting the structure of comparative subclauses, to be followed by a description of deletion phenomena provided in the third section. Section 4 will then overview the data from the Old Hungarian and partly from the Middle Hungarian period necessary for the present discussion; finally, in section 5 I will provide my analysis for the parametric changes.

\section{The structure of comparatives}

Let us consider the following example from Modern Hungarian:

(1) Anna ma több-ször telefonált-t-ø Moszkvá-ba, mint Ann today more-times phone-PST-3Sg Moscow-Illativus than a-hány-szor Miki szok-ott-ø. x-many-times Mike do-PST-3SG

'Ann phoned to Moscow more times today than Mike usually does.' 
A comparative construction contains two semantic elements: the reference value and the standard value of comparison. The reference value is expressed in the form of a $\mathrm{QP}$ (Quantifier Phrase) in the matrix clause (in this case, this is többször 'more times'), whereas the standard value is expressed by the comparative subclause itself (which is here mint ahányszor Miki volt 'than x-many times Mike was').

The comparative subclause is a CP (Complementiser Phrase), which is introduced by the C head mint 'than' in Modern Hungarian (see Kenesei 1992), representing comparative Force (see Rizzi 1999) ${ }^{2}$. There is yet another CP under the one headed by mint; and the specifier of this lower CP hosts the comparative operator moving there by operator movement (Chomsky 1977; Kennedy-Merchant 2000). The structure is schematically represented below:

(2)

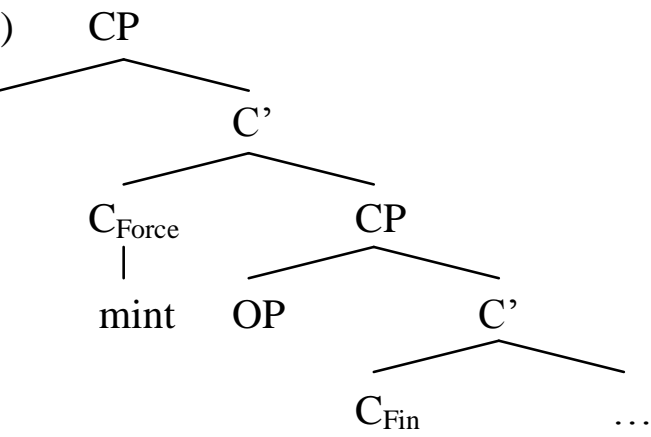

My representation follows Rizzi's analysis of the Left Periphery, who claims that there are two $\mathrm{CP}$ projections, the upper one being responsible for Force and the lower for Finiteness, and in between the two optional Topic and Focus phrases can be found, if any (Rizzi 1997: 297):

(3) $[\mathrm{CP}[$ TopP $[$ FocP $[$ TopP $[\mathrm{CP}]]]]]$

\footnotetext{
${ }^{2}$ Though Rizzi calls this "illocutionary Force", and distinguishes among declarative, interrogative, relative etc. types, this has very little to do with the notion of illocution in the sense of Austin and Searle, since the ones discussed by Rizzi are not performative sentence types. In order to avoid any possible terminological confusion, I will restrict myself to calling it "Force", as is normally done in the literature.
} 
As can be seen in (2), in Present-day Hungarian mint is generated in the upper C head position, while the operator moves to the specifier of the lower CP (see Kántor 2008a); as a matter of fact, the operator can be overt, as shown by (1) or by (4) below:

(4) Mari-nak több macská-ja van, mint a-hány macská-ja Péter-nek van. Mary-Dat more cat-Poss is than x-many cat-Poss Peter-DAt is 'Mary has more cats than Peter has.'

\section{Parametric variation in the subclause}

Before turning to the description of Old Hungarian comparatives, let us first examine one of the most important deletion processes specific to comparatives, namely Comparative Deletion (CD), which is subject to parametric variation with respect to its obligatoriness.

$\mathrm{CD}$ is an operation responsible for eliminating the QP from the comparative subclause in the $[\mathrm{Spec} ; \mathrm{CP}]$ position, if it is logically identical with the one in the matrix clause (Bácskai-Atkári 2010: 10). English is a [+CD] language, i.e. a language in which this operation is obligatory. ${ }^{3}$ Consider:

(5) a. *Ann is more enthusiastic than Peter is enthusiastic.

b. Ann is more enthusiastic than Peter is

The reason for the ungrammaticality of $(5 \mathrm{a})$ is that the QP in the subclause $(x$-much enthusiastic, which appears only as enthusiastic overtly) does not move up to [Spec; $\mathrm{CP}]$ and hence cannot be deleted there be $\mathrm{CD}$; however, since $\mathrm{CD}$ is obligatory in English, the result is clearly ungrammatical. On the other hand, (5b) is perfectly acceptable, since there movement and deletion do happen.

\footnotetext{
${ }^{3}$ Notions such as $[+\mathrm{CD}]$ and $[-\mathrm{CD}]$ are descriptive parameters only (in this respect similar to the notions SOV, SVO etc.). For details on how the actual process works, see Bácskai-Atkári (2010).
} 
It has to be mentioned that in some cases the QP is contained within a DP (Determiner Phrase); if so, the entire DP moves up and is deleted, otherwise there would be a DP island violation (see Izvorski 1995: 271; Kántor 2008b: 148-149; on the constraint itself, see Kayne 1983; Ross 1986; Bošković 2005; Grebenyova 2004). This is shown below:

(6) a. *Susan has bigger cats than Peter has cats.

b. Susan has bigger cats than Peter has

Unlike English, Present-day Hungarian is a [-CD] language, as proved by the following examples (see also examples (1) and (4) above):

(7) a. Anna lelkes-ebb, mint a-milyen lelkes Miki.

Ann enthusiastic-er than x-much enthusiastic Mike

'Ann is more enthusiastic than Mike.'

b. Zsuzsá-nak nagy-obb macská-i van-nak, mint a-milyen nagy macská-i

Susan-DAT big-er cats-Poss be-3PL than $\mathrm{x}$-much big cat-Poss

Péter-nek van-nak.

Peter-DAT be-.PL

'Susan has bigger cats than Peter.'

Since (7a) and (7b), the Hungarian counterparts of (5) and (6), are grammatical without the deletion of the operator, it can be concluded that Modern Hungarian is clearly a $[-C D]$ language, meaning that $\mathrm{CD}$ is not obligatory.

The question arises whether the situation was similar in Old Hungarian, too. Of course, there are obvious methodological difficulties concerning this: whereas the (systematic) appearance of an overt operator does in fact signify that the given language has a $[-C D]$ setting, this is not true vice versa because the absence of an overt operator may be well due to optional ellipsis and not to a $[+\mathrm{CD}]$ setting - and, assuming that the sentences found in the written texts from earlier periods are grammatical ones, there is no direct evidence on what was ungrammatical. Yet, as will be shown in section 5, there are some ways of finding reasons for a $[+\mathrm{CD}]$ pattern as well. 


\section{Diachronic change in Hungarian - an overview}

Let us now turn to the data from Old Hungarian and see what the most important stages were in the development of comparative subclauses. As has already been mentioned, the clause was initially introduced by hogy 'that'. The subclause contained the negative element nem 'not' as well (Haader 2003a: 515):

(8) a. Mert io-b hog megfog'dof-uā alg-uk-mèg' v because good-er that caught-PST.PTCP bless-3PL.SBJV-PREV Lord-ACC

hog ne méghal'-l'ōc

that not die-3PL.SBJV

'because it is better that we should bless the Lord caught than die'

(BécsiK. 25)

b. mert emberi elme, mindenkoron kezz-ebbaz gonozra, hog' because human mind always ready-er the evil-Sublativus that

nem az io-ra

not the good-Sublativus

'because the human mind is always readier for evil than for good'

(BodK. 2r)

Later mint 'than' could also appear in the structure, typically in the sequence hogy nem mint 'that not than'; this construction appeared already in the late Old Hungarian period but became characteristic of Middle Hungarian (Haader 2003a: 515, 2003b: 681):
(9) a. maftan kozel-b-en vagyon a'-my Idweffeeg-wnk honnem now near-er-SUPERESSIVUS is the-our salvation-3PL.Poss that.not
mynt eleeb hyt-t-ok
than before think-PST-3PL.
'our salvation is nearer now than we thought before'

(ÉrdyK. 3; ex. from Haader 2003a: 515) 
b. az men-tól also-bük-ban is tob angÿal uagon honnem

the all-ABL down-er-INESSIVUs also more angel is that.not

mÿnth az nap-nak fen-e-ben

than the sun-Dat light-Poss-INESSIVUs

'there are more angels in the basest one of them than in the sun's light'

(SándK. 1v)

It is worth mentioning that the heads hogy, nem (or sem 'neither'), and mint could also fuse (see Haader 2003a: 515; Kenesei 1992: 43), as is shown above by the fusion of hogy and nem into honnem. ${ }^{4}$

Later on, the negative element nem could also be left out, rending the sequence hogy mint (Haader 2003a: 515):

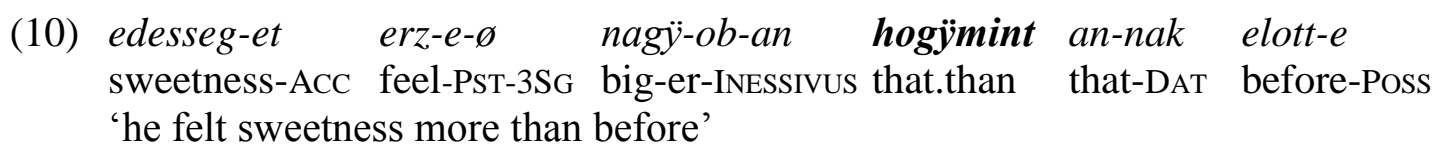
(LázK. 140; ex. from Haader 2003a: 515)

These are the main stages in the development of Hungarian comparative subclauses, the final one of course being a situation where the subclause is introduced only by mint:

(i) hogy nem

(ii) hogy nem mint / hogynem mint

(iii) hogy mint

(iv) mint

Before turning to the analysis and explanation of the phenomenon, consider the chart in Figure 1, which shows some data from the Old Hungarian corpus (in these texts I did not find any examples for the sequence hogy mint):

\footnotetext{
${ }^{4}$ The issue will be further examined in the next section.
} 


\begin{tabular}{|l|l|c|c|c|}
\hline Codex & Date & hogy nem & $\begin{array}{c}\text { hogy nem } \\
\text { mint }\end{array}$ & mint \\
\hline Jókai & btw. 1372 and 1448 & 3 & 4 & 4 \\
\hline Müncheni & 1466 & 3 & & \\
\hline Bécsi & btw. 1416 and 1450 & 15 & & 1 \\
\hline Birk & 1474 & 2 & 2 & \\
\hline Weszprémi & around 1512 & & 7 & \\
\hline Gömöry & 1516 & & 1 & 1 \\
\hline Sándor & around 1518 & 3 & 2 & \\
\hline Pozsonyi & 1520 & 3 & 1 & 2 \\
\hline Bod & after 1520 & 4 & & 3 \\
\hline Székelyudvarhelyi & $1526-1528$ & & 3 & \\
\hline
\end{tabular}

Figure 1: Some data from the Old Hungarian corpus

It has to be mentioned that the chart does not cover all the data from Old Hungarian, i.e. there are other texts as well that might contain comparative subclauses of the sort concerned here, while there were some which included apparently none. However, what is important here is not really the number of the instances of each type but rather the relative distribution thereof. As has been already said, the earliest type was hogy nem, to be followed by hogy nem mint, and it is only the final stage where we have mint only. It should be obvious that although the diachronic development of the individual constructions is so, the actual occurrences of these do not strictly reflect this order. For instance, the earliest text, the Jókai-Codex, contains all the three constructions to about the same extent, whereas the Bécsi Codex (Vienna Codex) almost exclusively uses the earliest form hogy nem. On the other hand, late examples such as the Bod-Codex still contain a relatively large amount of hogy nem, in spite of featuring examples containing mint.

This is important because it explicitly shows that the various types of constructions did not strictly follow each other, and - as can be expected - there was considerably overlapping in the period; consequently, the late Old Hungarian (and also the early Middle Hungarian) period was one with several changes and these are reflected in the co-occurrence of the forms in the texts for considerable time. This also implies that the individual stages of the change 
used in the description to be presented in the next section are not meant to be strictly distinguishable periods, and are used rather to facilitate the description of the change; however, in the actual language use these steps did feature simultaneously for quite a long time and thus the change was far from being abrupt.

\section{Reanalysis and parametric change}

Let us now turn to the analysis of the diachronic change concerning comparatives in Hungarian. There will be two points to focus on: the status of the $\mathrm{C}$ heads and the deletion of the comparative operator.

\subsection{The initial setup}

Initially, as has already been mentioned, the comparative subclause was introduced by the $\mathrm{C}_{\text {Force }}$ head hogy 'that'. At this stage, the comparative operator was subject to obligatory Comparative Deletion - thus Old Hungarian initially had a $[+\mathrm{CD}]$ parameter. $^{5}$ On the other hand, the subclause also contained the negative element nem 'not', which was probably required by the comparative Force of the clause originally (later the negative element disappeared from the construction, as comparative Force is not universally accompanied by negation, see e.g. Modern Hungarian).

The situation with respect to the structure of the two CPs is schematised below:

\footnotetext{
${ }^{5}$ How this can be proved will be explained later on; for the time being, let us concentrate on the description of the initial pattern.
} 


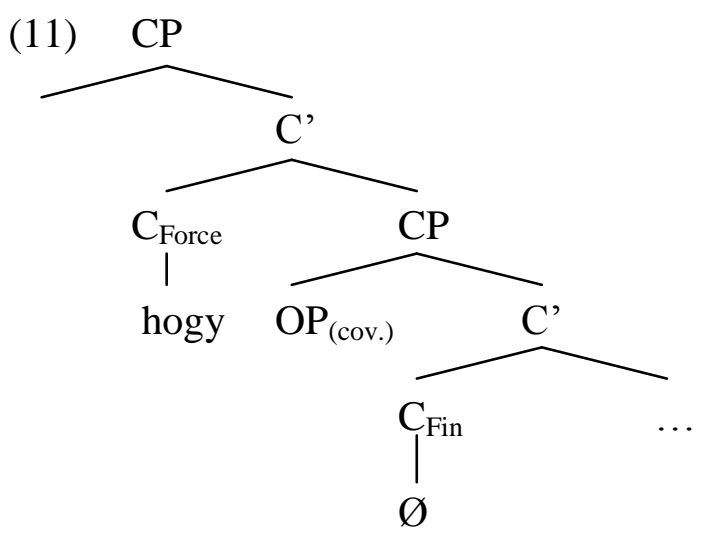

As can be seen, hogy is a C head; historically, though, Haader (2003a: 515; 2003c: 263) and Juhász (1991: 479) derive it from a relative pronoun of the same form (functionally equivalent with the present-day relative pronoun ahogy 'how'). Although this seems plausible, since there is no direct evidence for the hypothesis, I will not venture either to defend or to refute it but simply remark that this may have been a possible source for the $\mathrm{C}$ head. What is more important for us is that at the beginning of the Old Hungarian period it was already a complementiser and not a relative pronoun. Evidence for this partly stems from the fact that hogy was able to fuse with other heads (see section 4 above) - hence it was a head and not a phrase. On the other hand, hogy introduced other types of finite clauses as well in the period under scrutiny: both that-clauses and ordinary relative clauses (Haader 2003a, 1991; Galambos 1907).

This configuration - i.e. that the $\mathrm{C}$ head introducing comparatives can be found in other subclauses as well - is one that can be found in other languages, thus the Old Hungarian setup is not unique cross-linguistically. For instance, it is quite frequent in Latinate languages, such as Italian or French: Italian che or French que introduce not only comparative subclauses but also ordinary relatives clauses and that-clauses - and both are $\mathrm{C}_{\text {Force }}$ heads (see Rizzi 1997; Rowlett 2007: 147-148). The comparative clauses introduced by them are shown below: 
(12) Maria mangi-a più che Paolo. Mary eat-3Sg more that Paul

'Mary eats more than Paul.'

(13) Anne est plus fatigué-e que Marie.

Ann is more tired-F that Mary

'Ann is more tired than Mary.'

To conclude, it seems that the representation in (11) is supported also by cross-linguistic data and will be used in the present paper as the basis of representing the Old Hungarian structures.

\subsection{The relation of hogy and hogy nem}

Let us now briefly turn to the status of the negative element, though this is - as said before not going to be a central question of this essay. First of all, the presence of a negative element is familiar from other languages as well (see Salvi-Vanelli 2004: 283-285) - far from attempting to provide a complete list, let us consider the following Italian and French examples ${ }^{6}$ :

(14) Maria mangi-a più che non Paolo. Mary eat-3Sg more that not Paul 'Mary eats more than Paul.'

(15) L'-example touch-e plus que ne fai-t la menace. the-example touch-3Sg more that not do-3SG the(F) threat 'Examples touch more than threat does.' (Corneille)

It must be noted that the presence of the negative element is far from being obligatory, as can be seen from the Italian pair of (12) and (14), where the latter differs from the former only in style, in being more formal or elevated. I will not engage in analysing these differences, nor will I venture to examine the status of ne with respect to actual negation in

\footnotetext{
${ }^{6}$ A similar phenomenon can be traced in Cockney English and partly also in Standard English, with respect to the acceptability of negative polarity items in the subclause, see Seuren (1973).
} 
Modern French; suffice it to say that though the negative function of these elements is no longer evident today, their origin is so, as is the case with the Old Hungarian hogy nem.

With respect to the status of hogy nem, however, there is one more important question: namely that the elements hogy and nem could actually fuse, resulting in the complex $\mathrm{C}$ head hogynem (see Juhász 1991: 489, 494); also, this process could be accompanied by a phonological change, rending honnem, pronounced as [hon:\&m] instead of [hofn\&m]:

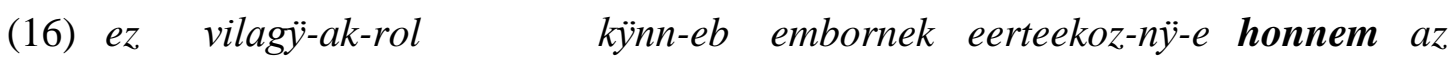
this mundane-PL-Delativus easy-er man-Dat dissert-INF-3Sg that.not the

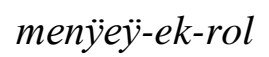
heavenly-PL-DELATIVUS

'it is easier for man to dissert on mundane than on heavenly matters'

(SándK. 1r)

It seems thus that in Old Hungarian there evolved two C heads: hogy and hogynem. The importance of keeping hogy as a $\mathrm{C}$ head on its own becomes clear when considering the later string hogy mint besides hogy nem mint, which contains no negative element. This is easily explained by saying that when mint appeared, it could be used both in the construction introduced by hogynem and in the one with hogy nem, the latter to be simplified into hogy solely and the former disappearing altogether. If one were to suppose that there existed only hogynem, it would also require one to resort to the rather implausible solution of saying that the bound morpheme nem was lost from the middle of the string hogynem mint.

\subsection{The relative cycle as a grammaticalization process}

For the analysis of the diachronic change in question, it is necessary to present a grammaticalization process called the relative cycle, which will be claimed to be one of the key factors inducing changes in Old Hungarian comparatives. 
The relative cycle is basically a process where an original determiner becomes first a relative operator, and subsequently the relative operator is reanalysed as a C head (RobertsRoussou 2003: 119, van Gelderen 2009). This kind of change happened to the English that during the Old English period, which was originally a determiner (this function being preserved in the D head in Present-day English as well) but was used also as a relative pronoun. However, the relative pronoun moving to [Spec; $\mathrm{CP}$ ] came to be analysed later as part of the $\mathrm{CP}$, i.e. as a $\mathrm{C}$ head. First that was interpreted as a $\mathrm{C}_{\mathrm{Fin}}$ head but later was reanalysed from the $\mathrm{C}_{\text {Force }}$ head, as shown by van Gelderen (2009: 107).

The processes described above are schematically drawn below:

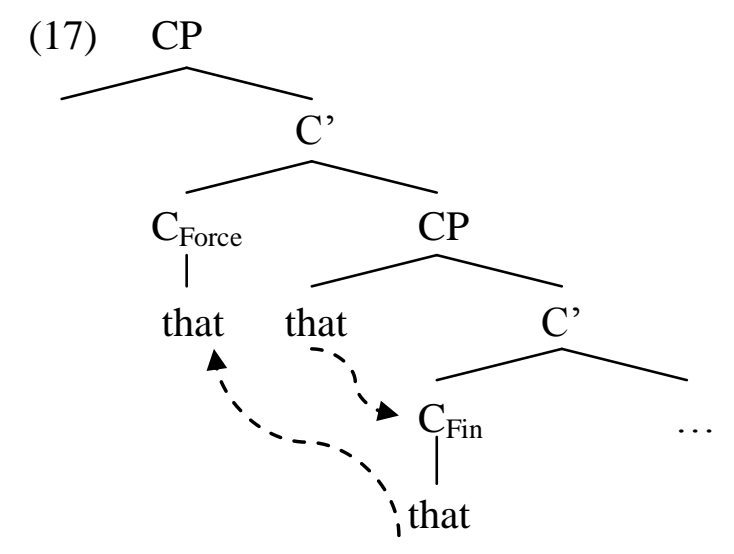

As can be seen, the element that first occupied the specifier position of the lower CP, then it was reanalysed as the head thereof, and finally was base-generated as the head of the higher CP.

\subsection{The appearance of mint}

The appearance of mint in Old Hungarian comparative subclauses has an interesting parallel phenomenon in relative clauses, which is not quite unprecedented as comparatives generally tend to have an analogous structure with ordinary relatives. Though, as will be shown, the 
development of the two structures in Hungarian seem to have been fed from two different directions, the resulting structures show many common aspects, which will be helpful for the present analysis.

In Old Hungarian but especially in Middle Hungarian, relative clauses were frequently introduced by the string hogy + a relative pronoun (see Galambos 1907: 14-18; see also Haader 1995; Dömötör 1995) - this could ultimately also become a complex complementiser (Juhász 1992: 792; Haader 1995). ${ }^{7}$ The structure is illustrated below:

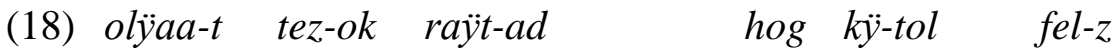 such-ACC do-1SG you-SUPERESSIvus that what-ABL fear-2SG 'I will do such to you that from which you will fear'

(SándK. 14v)

Phonologically, there is no difference between the interrogative and the relative pronoun: the distinction between the two (i.e. present-day $k i$ 'who-Int.' and $a k i$ 'who-Rel.') started to emerge only in the late Old Hungarian period but was not completed then (Sipos 1991: 398; G. Varga 1992: 524-525; Juhász 1992: 791; Haader 1995).

The structure of the Left Periphery of the subclause is shown below:

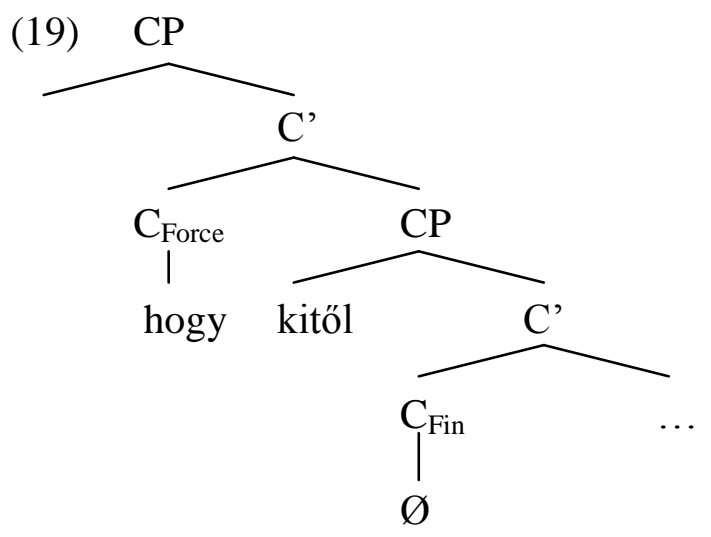

As can be seen, the higher CP is headed by hogy, while the lower CP has a $\varnothing$ as its head and a relative operator (e.g. kitöl) in its specifier. For the explanation of the phenomenon the

\footnotetext{
${ }^{7}$ It is worth mentioning that this type of configuration (i.e. hogy + relative pronoun) has disappeared from the language. To investigate the reasons for this would be far beyond the scope of the present article and therefore I will leave this question here open.
} 
hypothesis of Galambos (1907: 15) was that the relative pronoun was in this period still closer to its original pronominal function and hogy was at least partly used to reinforce it as an operator, whereas later it became redundant. On the other hand, the construction expresses consequence besides being a relative clause, thus it was not merely a structural variant. Nevertheless, it seems that the first step of the relative cycle, i.e. whereby the determiner started to be used as an operator, was not far from this period.

More importantly, a similar construction can be found in comparatives from the same period: like the relative operator, the comparative operator mint started to appear in the lower [Spec; CP]; actually, this was a relative pronoun in the period (see Juhász 1991: 480-481), in examples like the following:

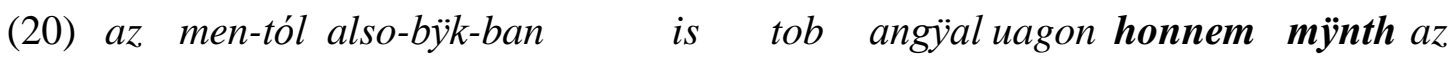
the all-ABL down-er-INESSIvUs also more angel is that.not than the nap-nak fen-e-ben sun-DAT light-POSS-INESSIVUS

'there are more angels in the basest one of them than in the sun's light'

(SándK. 1v)

It should not be surprising that mint did not phonologically show its operator status, as it was true for other relative operators in the period that phonologically they had the same forms as $w h$-pronouns used in main clause questions (e.g. $k i$ 'who-Int.' vs. $k i$ 'who-Rel.). Thus the fact that no functional split can be seen (as between present-day $k i$ 'who-Int.' and $a k i$ 'whoRel.) and the operator mint does not feature as amint, is not exceptional.

The structure is shown below: 


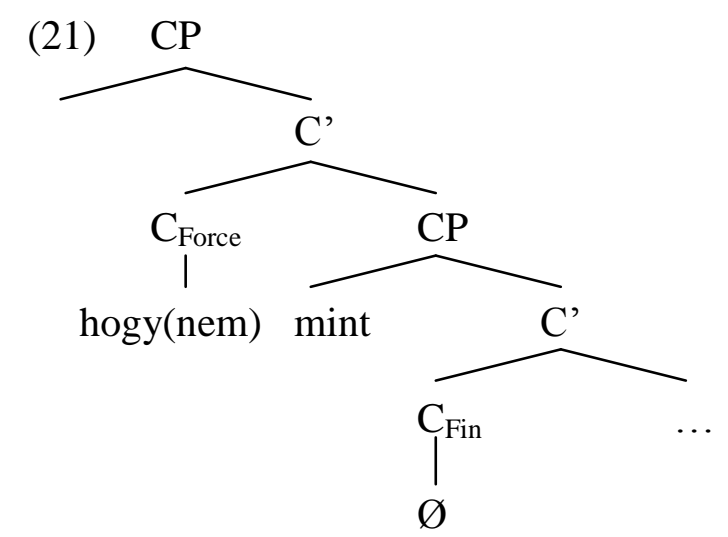

Thus the upper $\mathrm{C}$ head is still filled by hogy or hogynem, the lower CP is headed by a Ø; however, in the specifier of the lower $\mathrm{CP}$ one can find an overt operator, mint. Fusion was possible, as was in the case of relative operators (see Juhász 1992: 792; Haader 1995). It has to be noted that although the structures in (19) and (21) are fundamentally the same, they developed exactly from the opposite directions, i.e. in the case of comparatives hogy was present first and the operator appeared later, while in the case of relative clauses the operator was there originally and hogy was inserted only later (and did in fact disappear ultimately, unlike mint in comparatives). Nevertheless, the strict similarity is important because in terms of the resulting structure, they are the same; on the other hand, the comparative structure could be reinforced by analogy from relative clauses.

The appearance of mint was possible because there was no other operator available in comparatives; a similar phenomenon can be traced in other [+CD] languages, as illustrated below by English on (22a) and by German in (22b) and (22c):

(22) a. \% John is taller than what Mary is. (Chomsky 1977: 87, ex. 51a)

b. \% Die Welt ist mehr, als was wir seh-en. the(F) world is more than what we see-1PL

'The world is more than what we see.'

c. \% Er ist besser als wie $d u$. he is better than how you 'He is better than you.' 
The constructions, as indicated, are only marginally acceptable, though in some dialects they can be perfectly grammatical (e.g. (22a) is so in New England English, whereas it would be very marked in Standard British English). What can be seen is that the $\mathrm{C}$ head than and its German equivalent als can be followed by relative operators such as what and was or wie. This is exactly the case for Old Hungarian mint, with the only difference that it seems not to have been marginal in late Old Hungarian and Middle Hungarian, as shown by its frequent appearance in the texts.

These operators, including mint in Old Hungarian, do not show any sensitivity to the subtype of comparative they appear in, whereas in Modern Hungarian there is rich morphological variety in comparative operators, with respect to the type of comparative (i.e. whether it is predicative or attributive etc.). Operators like Old Hungarian mint or the English what are proforms standing for the entire QP or DP, which also means that these QPs and DPs will not include a lexical AP (Adjective/Adverb Phrase) or NP (Noun Phrase), as would be possible in present-day Hungarian (see the examples in (7) for this), which is a $[-\mathrm{CD}]$ language. This is not surprising inasmuch as even in late Old Hungarian, the relative pronouns milyen/amilyen 'how', mekkoralamekkora 'how big' were still missing (see G. Varga 1992: 525), which are otherwise readily combined with lexical APs or NPs in Modern Hungarian.

As the behaviour of Old Hungarian mint in comparatives correlates with that of comparative operators in other $[+\mathrm{CD}]$ languages, it seems reasonable to claim that originally Old Hungarian was a $[+\mathrm{CD}]$ language too, and only later changes resulted in the present-day $[-\mathrm{CD}]$ pattern. 


\subsection{The reanalysis of mint}

The next step in the development of mint was basically the second step of the relative cycle, i.e. an operator being reanalysed as a $\mathrm{C}$ head. Thus the original operator mint started to be analysed as generated in the $\mathrm{C}_{\text {Fin }}$ head, while the $\mathrm{C}_{\text {Force }}$ head still contained hogy(nem).

Admittedly, it is in most cases impossible to detect in a given example of the string hogy nem mint whether mint was a $\mathrm{C}$ head or still an operator; however, by looking at a large corpus it can be proved that the change did take place during the Middle Hungarian period. First, unlike ordinary relative operators from the period, mint remained insensitive to the choice of the matrix pronominal element (Juhász 1992: 799), though as an operator it should have shown changes accordingly (i.e. it would not have been possible to have mint invariably after various matrix pronominal elements like annyiszor 'many times', akkora 'much big', olyan 'how'). On the other hand, it did not develop into a proper operator morphologically, unlike relative pronouns, which started to be distinguished from wh-operators in their overt forms - for instance, showing a difference between $k i$ 'who-Int.' and aki 'who-Rel.'. These indicate that mint was no longer a relative pronoun but a $\mathrm{C}$ head, and as such it naturally did not show the changes indicated above.

The structure was thus the following:

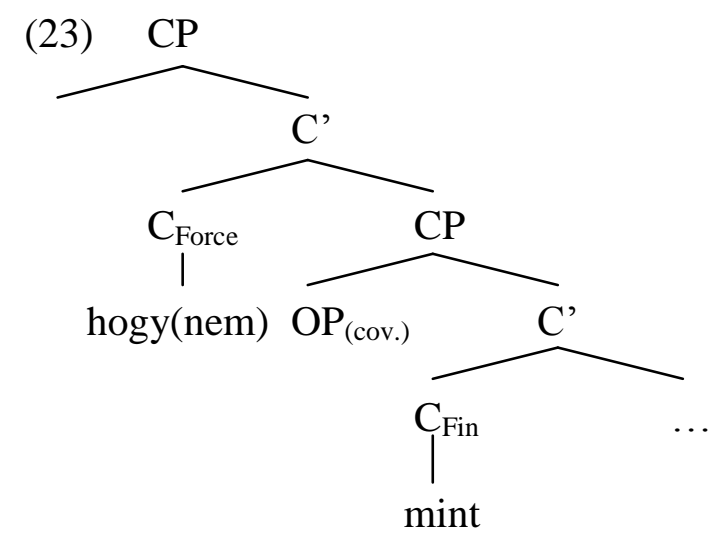


As can be seen, there were two $\mathrm{C}$ heads filled, the upper by hogy(nem), whereas the lower by mint. At this stage, the specifier of the lower CP could contain only a covert operator, which is not surprising since otherwise there would have been a violation of the Doubly Filled Complementiser Filter.

\subsection{Reanalysis in terms of the two $C$ heads}

The final step concerns the development of mint into a $\mathrm{C}_{\text {Force }}$ head: this process meant the reanalysis of mint from the $\mathrm{C}_{\text {Fin }}$ to the $\mathrm{C}_{\text {Force }}$ head, and was in parallel with the disappearance of hogy. On the one hand, the fact that mint was analysed as a head responsible for the comparative Force required it to be base-generated in the relevant position, thus inducing a structural change and making hogy disappear. On the other hand, the disappearance of hogy from the construction made it possible for mint to start occupying the upper $\mathrm{C}$ head.

By mint appearing in the upper $\mathrm{C}$ head, it was possible for the comparative operator to appear in the specifier of the lower CP again, which is actually similar to the first step of the relative cycle. This time, however, operators were relative pronouns (such as amennyi ' $\mathrm{x}$ many, ahányszor 'x-many times', amilyen 'x-much' etc.) and this can be attributed to analogy with ordinary relative clauses. These do allow the co-presence of a lexical AP or NP, and the language no longer has a $[+\mathrm{CD}]$ pattern. $^{8}$

Interestingly, the use of these comparative operators together with mint, as described by Galambos (1907), was a point of disapproval for purists such as Zsigmond Simonyi, for the

\footnotetext{
${ }^{8}$ The scope of the present article does not allow to provide a complete analysis of the parametric setting that would show which language is $[+\mathrm{CD}]$ and which is $[-\mathrm{CD}]$. My hypothesis is that this is primarily a morphological difference: languages having a comparative operator that can be combined with a lexical NP or $\mathrm{AP}$ will be $[-\mathrm{CD}]$ languages, whereas in languages where there is not (either because there is no operator at all or because there is only a fundamentally invariable proform available, which stands for the entire DP or QP), the parametric setting will be $[+\mathrm{CD}]$. Though this is true descriptively, the real question would rather be why this should be so - this, however, is far beyond the scope of the present analysis.
} 
reason that they found the operator appearing after mint unnecessary. However, the copresence of the $\mathrm{C}$ head and an operator in this case is just the repetition of a diachronic change which actually produced mint to be the $\mathrm{C}$ head introducing comparatives at all.

The structure of the final stage is shown below:

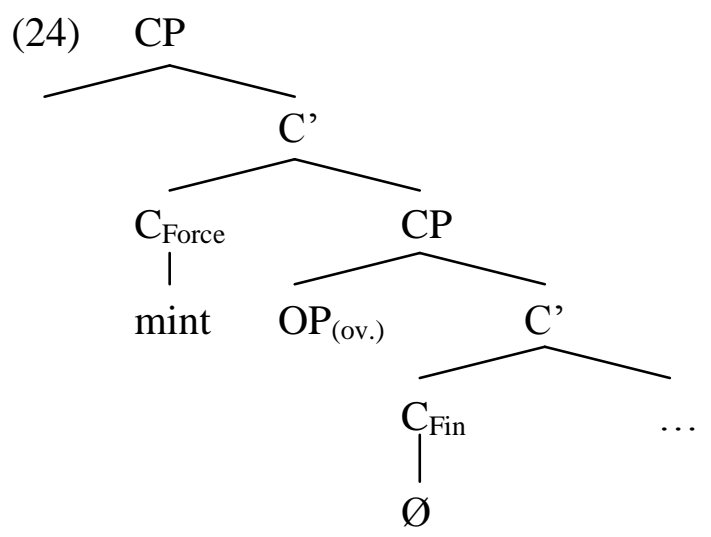

Showing the present-day configuration, (24) highlights that mint is located in the upper $\mathrm{C}$ head, the lower $\mathrm{CP}$ being headed by a $\varnothing$ complementiser, with its specifier possibly hosting an overt comparative operator.

\section{Conclusion}

The aim of this research was to investigate the development of Hungarian comparative subclauses, with special attention to the complementiser(s) and the operator. As was shown, the history of the complementiser and that of the operator are two interrelated processes, so much so that the present-day $\mathrm{C}$ head derives from the first overt operator. One of the most important aspects was that the changes can be analysed in terms of the relative cycle, which made mint to be reanalysed as a complementiser. Second, the appearance of the operator itself is strongly connected to the processes going on in ordinary relative clauses, as several steps in 
the development of comparatives can be attributed to analogy with relative clauses. Last but not least, there was also a parametric setting to be changed in the deletion of the operator: the initial $[+\mathrm{CD}]$ pattern changed to $[-\mathrm{CD}]$.

Bearing all these aspects in mind, despite the fact that overtly the Old Hungarian comparative structure is considerably different from the one in Present-day Hungarian, it can be shown that the latter derives from the former directly.

\section{References}

Bácskai-Atkári, Júlia. 2010. "Parametric Variation and Comparative Deletion”. The Even Yearbook 9. 1-21.

Bošković, Željko. 2005. "On the Locality of Left Branch Extraction and the Structure of NP”. Studia Linguistica 59:1. 1-45.

Chomsky, Noam. 1977. “On WH-movement”. Formal Syntax ed. by Peter W. Culicover et al., 71-132. New York: Academic Press.

Dömötör, Adrienne. 1995. “Az alárendelő mondatok: A jelzői mellékmondatok”. A magyar nyelv történeti nyelvtana II/2.: A kései ómagyar kor: Mondattan. Szöveggrammatika ed. by Loránd Benkő, 666-693. Budapest: Akadémiai Kiadó.

Galambos, Dezső. 1907. Tanulmányok a magyar relatívum mondattanáról. Budapest: Athenaeum.

Grebenyova, Lydia. 2004. "Sluicing and Left-Branch Extraction out of Islands". WCCFL 23: The Proceedings of the 23rd West Coast Conference on Formal Linguistics ed. by Vineeta Chand et al., 164-172. Somerville, Mass.: Cascadilla Press.

G. Varga, Györgyi. 1992. "A névmások”. A magyar nyelv történeti nyelvtana II/1.: A kései ómagyar kor: Morfematika ed. by Loránd Benkő, 455-569. Budapest: Akadémiai Kiadó. 
Haader, Lea. 1991. “Az alárendelő mondatok: Az alanyi, állítmányi, tárgyi és határozói mellékmondatok". A magyar nyelv történeti nyelvtana I.: A korai ómagyar kor és elözményei ed. by Loránd Benkő, 728-741. Budapest: Akadémiai Kiadó.

Haader, Lea. 1995. “Az alárendelő mondatok: Az alanyi, állítmányi, tárgyi és határozói mellékmondatok". A magyar nyelv történeti nyelvtana II/2.: A kései ómagyar kor: Mondattan. Szöveggrammatika ed. by Loránd Benkő, 506-665. Budapest: Akadémiai Kiadó.

Haader, Lea. 2003a. "Az ómagyar kor: Mondattörténet: Az összetett mondat”. Magyar nyelvtörténet ed. by Jenő Kiss \& Ferenc Pusztai, 500-560. Budapest: Osiris Kiadó.

Haader, Lea. 2003b. “A középmagyar kor: Mondattörténet: Az összetett mondat”. Magyar nyelvtörténet ed. by Jenő Kiss \& Ferenc Pusztai, 677-690. Budapest: Osiris Kiadó.

Haader, Lea. 2003c. “Az ősmagyar kor: Mondattörténet: Az összetett mondat”. Magyar nyelvtörténet ed. by Jenő Kiss \& Ferenc Pusztai, 260-267. Budapest: Osiris Kiadó.

Izvorski, Roumyana. 1995. "A Solution to the Subcomparative Paradox". WCCFL 14: The Proceedings of the 14th West Coast Conference on Formal Linguistics ed. by Jose Camacho et al., 203-219. Stanford: CSLI Publications.

Juhász, Dezső. 1991. “A kötőszók”. A magyar nyelv történeti nyelvtana I.: A korai ómagyar kor és elözményei ed. by Loránd Benkő, 476-500. Budapest: Akadémiai Kiadó.

Juhász, Dezső. 1992. “A kötőszók”. A magyar nyelv történeti nyelvtana II/1.: A kései ómagyar kor: Morfematika ed. by Loránd Benkő, 772-814. Budapest: Akadémiai Kiadó.

Kántor, Gergely. 2008a. “On Hungarian Relative Operators”. The Even Yearbook 8. 1-12.

Kántor, Gergely. 2008b. “Komparatív korrelatív szerkezetek a magyarban”. Nyelvtudományi Közlemények 105. 134-163.

Kayne, Richard. 1983. “Connectedness”. Linguistic Inquiry 14. 223-250.

Kenesei, István. 1992. “On Hungarian Complementizers”. Approaches to Hungarian 4 ed. by István Kenesei \& Csaba Pléh, 37-50. Szeged: JATE.

Kennedy, Christopher \& Jason Merchant. 2000. “Attributive Comparative Deletion”. Natural Language \& Linguistic Theory 18. 89-146.

Rizzi, Luigi. 1997. "The Fine Structure of the Left Periphery”. Elements of Grammar ed. by Liliane Haegeman, 281-337. Dordrecht: Kluwer. 
Rizzi, Luigi. 1999. On the Position "Int(errogative)" in the Left Periphery of the Clause. Retrieved March 31 2008, from http://www.ciscl.unisi.it/persone/rizzi.htm.

Roberts, Ian \& Anna Roussou. 2003. Syntactic Change: A Minimalist Approach to Grammaticalization. Cambridge: Cambridge University Press.

Ross, John Robert. 1986. Infinite syntax. Norwood: Ablex Publishing.

Rowlett, Paul. 2007. The Syntax of French. Cambridge: Cambridge University Press.

Salvi, Giampaolo \& Laura Vanelli. 2004. Nuova grammatica italiana. Bologna: il Mulino.

Seuren, Pieter. 1973. "The Comparative". Generative Grammar in Europe ed. by Ferenc Kiefer \& Nicolas Ruwet, 528-564. Dordrecht: D. Reidel.

Sipos, Pál. 1991. “A névmások". A magyar nyelv történeti nyelvtana I.: A korai ómagyar kor és elözményei ed. by Loránd Benkő, 353-400. Budapest: Akadémiai Kiadó.

van Gelderen, Elly. 2009. "Renewal in the Left Periphery: Economy and the Complementiser Layer". Transactions of the Philological Society 107:2. 131-195. 